\title{
Article
}

\section{'Ten Years Ahead of His Time': The East End Elegance of Martin Peters}

\author{
Hughson, John Ewing \\ Available at http://clok.uclan.ac.uk/13571/
}

Hughson, John Ewing ORCID: 0000-0002-7030-4806 (2015) 'Ten Years Ahead of His Time': The East End Elegance of Martin Peters. Sport in History, 35 (1). pp. 108-126. ISSN 1746-0263

It is advisable to refer to the publisher's version if you intend to cite from the work. http://dx.doi.org/10.1080/17460263.2014.926287

For more information about UCLan's research in this area go to

http://www.uclan.ac.uk/researchgroups/ and search for <name of research Group>.

For information about Research generally at UCLan please go to http://www.uclan.ac.uk/research/

All outputs in CLoK are protected by Intellectual Property Rights law, including Copyright law. Copyright, IPR and Moral Rights for the works on this site are retained by the individual authors and/or other copyright owners. Terms and conditions for use of this material are defined in the policies page.

\section{CLoK}

Central Lancashire online Knowledge www.clok.uclan.ac.uk

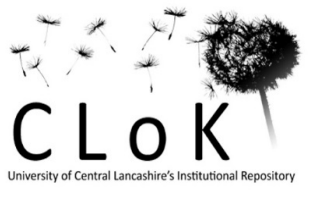




\title{
“Ten Years Ahead of His Time': The East End Elegance of Martin Peters'
}

\author{
John Hughson, University of Central Lancashire, UK
}

\begin{abstract}
Martin Peters was a successful footballer whose public persona matched the way he played the game, without fuss or fanfare. A key English player of the 1960s, he does not usually feature in discussions about the connection between fashion and football in that decade. The focus is usually placed on players with celebrity status, especially George Best. This paper, working at the intersection of sport and fashion history and cultural studies, broadens the discussion by giving consideration to the non-celebrity type player. This is done via an examination of the off-field dress and style of Martin Peters. The case is made, from studying the sartorial presentation of Peters, that we can recognize a connection between the player and other young men who favoured a low key identification with the Mod culture of the time. This position supports a shift within the cultural historical study of British youth and masculine identity from the spectacular to the unspectacular.
\end{abstract}

Keywords: 1960s, fashion, football, 'incorporation', Mod, style

'Peters might not be a goalscorer to equal Greaves at his best, but he has always been an elegant, graceful footballer with an eye for an opening.' (1)

\section{Introduction}

In J anuary 1968, following a drawn European Championship and Home International match against Scotland, England manager Sir Alf Ramsey claimed, in regard to the scorer of his team's only goal, 'Martin Peters is a player ten years ahead of his time'. (2) Peters had been a member of England's World Cup winning team in 1966 and he became a mainstay within Ramsey's sides thereafter. Ramsey's 1968 remark is somewhat defensive towards his player. As well as reaffirming his own shrewdness in 
selecting Peters in 1966, ahead of more conventional wingers, Ramsey spoke to those for whom Peters tended to go unnoticed as a player, those who focussed on the more obvious starring players such as Bobby Charlton, Bobby Moore and Gordon Banks. Peters was ten years ahead of his time, from Ramsey's prophetic view, because he evinced such versatility and completeness as a player that he could occupy any position on the pitch in the manner of 'total football', the type to become associated with the Holland national team of the mid-1970s. In personal style, Peters was not ahead of his time, but very much a young man of his time. But the relevance of the Ramsey quote applies to the extent that it prompts consideration of Peters going rather unnoticed in the fashion related stakes of professional football in the 1960s. A case is made in this paper for a revaluation of Peters' fashion status, according to the criteria of a proposed new category - the 'quiet Mod' - in comparison to the footballer related fashion categories of 'Mod Formal' and 'Mod Casual', developed by Hewitt and Baxter. (3) This new category is also used to critique historical typologies of football players, especially the typology set out by Chas Critcher. (4) The focus on Martin Peters works towards a conclusion arguing for the cultural historical significance of examining the fashion image of the non-celebrity player.

\section{Footballer 'Mod': from formal to casual}

It is often said that West Ham United won England the World Cup in 1966. (5) The claim is attributable to the goals for England, three from Geoff Hurst and one from Martin Peters, being scored by West Ham players, and to the deft passes from Bobby Moore to Hurst for two of his goals. That the Hurst, Moore and Peters trio provided the most numerous contingent of players from one club in the Final winning team, is also behind the claim. Of the trio, Peters has remained the least prominent, certainly in regard to recollections of the 1966 World Cup. Peters gives recognition in his most recent autobiography to the familiarly stated ordering of Moore / Hurst / Peters. (6) Indeed, the very title of the book, The Ghost of ' 66 , is at once referring to Peters' style of play - drifting unseen by opponents into dangerous attacking positions - and his existence in the shadows of Hurst and Moore's limelight. As Peters himself claims, 1966 related fame may well have favoured him over Hurst but for a twist of football 
fate. (7) Had Germany not been awarded a rather dubious free kick, from which they scored in the final seconds of regular time, Peters' goal, scored approximately thirteen minutes from fulltime, would have been the match winner, settling the result 2-1 to England. As it was, the match went into extra-time, during which Hurst scored a further two unanswered goals, making him the first (and still only) player to score a hat-trick in the Final of a World Cup tournament. Apart from Hurst's undeniably extraordinary goal scoring achievement in the 1966 World Cup Final, Peters may well have trumped him in the West Ham trio pecking order.

However, there was perhaps little Peters could have done on the field to have him rival the fame of Booby Moore. As Peters himself remarks, 'Bobby Moore was an iconic figure in the 1960s'. Peters refers to Moore's status in the 'world game', but his reference to Moore as an icon during the headiest of post-war decades speaks to his wider public identity in Britain. Moore personified one of the key fashion markers from which Peters' sartorial identification is established in this paper. The dashing young West Ham United captain, who lifted the FA Cup and the European Cup Winners Cup at Wembley in the two years previous to the World Cup, provided the benchmark within football for a category defined by Hewitt and Baxter as 'Mod formal'. (8) Moore's fastidiousness about and cleanliness in appearance has often been remarked upon. These qualities claim Hewitt and Baxter, tally with a 'smart look', more formal than casual. Accordingly, Moore was likely to be seen wearing tailored shirts and suits. In less formal mode he favoured cashmere polo neck pullovers or a jacket and trousers, rather than jeans. (9) Martin Peters provides his own memory of Moore's smartness, referring to a train journey with the West Ham team in 1967: 'As usual, Bobby was wearing a Savile Row suit, with shirt cuffs thrust forward to reveal smart cufflinks'. (10)

Hewitt and Baxter associate Moore with an early Mod look, which was actually termed 'Modernist' in the late 1950s. It emerged when jazz musicians such as Miles Davis appropriated the Ivy League style of earlier generations of white American men, who wore button-down shirts, suits made from mohair or similar materials and penny loafer shoes. This was a rebellious fashion statement, taking on, as it did, the look of middleclass, white, masculinity; locating it within a cultural context that was initially reviled 
by those who sported the borrowed-from look. That same look came to Britain as jazz took on a subcultural following in London clubs in the 1950s and thus became one of the styles of cool white masculinity in the pre-1960s period. (11) Moore, born in 1941, was not old enough to ride the wave of this style as it broke in Britain, but his sleek appearance exemplified its continuing influence. He was not quite young enough to be part of the generation that revered The Beatles and - although there are sartorial overlaps - did not go along with the fashion trends inspired by that famous band and their musical contemporaries. Indeed, Hewitt and Baxter suggest that the incipient rock music culture would not have appealed to Moore as it was too unruly for his ordered manner of living and related outlook. So the neat dress of the earlier jazz culture suited Moore superbly, matching his self-assuredness and 'unassailable confidence' as a football player. They furthermore suggest that Moore had exactly the right image for England's football captain in this period when a lingering collective mentality of hardship from the war years was coming to terms with the shiny new age of consumerist society. (12) Youthful and stylish, yet unemotional and not too flash, Moore struck the perfect balance to appeal to both young and old during this time of cultural flux.

Moore's 'Mod formal' style stands in contrast the 'Mod casual' style, most readily associated with the proto-maverick football genius George Best. Born in 1946, thus five years younger than Moore, Best debuted for the Manchester United first team at seventeen years of age in September 1963, within weeks of the single 'She Loves You' by The Beatles being released for sale in the UK. (13) Following an outstanding performance in Manchester United's away European Cup quarter-final tie against Benfica in March 1966, Best was dubbed O Quinto Beatle (the Fifth Beatle) by the Portuguese press because his mop-topped appearance was regarded as similar to that of the members of the by then famous band nicknamed the Fab Four. (14) A retiring teenager when he first came to Manchester United, Best soon lost his shyness, due largely to the unique pop star cult status he quickly acquired. (15) A straight-laced dresser upon arrival, Best was converted into a fashion plate to match this status. He was naturally gifted with not only sublime footballing talent, but also chiselled facial features rarely possessed by pop stars, let alone footballers. His emergence as a high 
profile player in the mid-1960s, following the end of the maximum wage for footballers in 1961, was well-timed. Although the subsequent improvement to player's salaries was slight in comparison to the massive relative amounts earned by those in the present Premier League era, Best embraced an image of celebrity extravagance, seemingly matched by a hedonistic rock star lifestyle. However there was a price to pay, as Best burned out as a leading player by the end of the 1960s, barely in his mid20s. (16)

In an act approximating rock star mythology, and in total contrast to the behaviour customarily expected of footballers, Best abandoned his playing commitments with Manchester United in December 1972 to go nightclubbing in London. After a series of faltering reconciliations he left Old Trafford for good in 1974. Best had become dissatisfied with the sliding fortunes of Manchester United in the Football League and seemed to have tired of the strictures involved with being a professional footballer. Best was no fan of set team tactics and game plans, and although quiet and courteous towards managers he chose to ignore their chastisements of his misconduct. (17) Best was an individualist who could not be shackled and the more elevated his standing as a player became the more he rejected football's organisational authority. The nonconformism was reflected in Best's attitude to off-field attire. While he has been photographed in suits, early on in a slim fit mod suit à la The Beatles, later in a doublebreasted three button suit, he is reported to have generally regarded suits as old fashioned. Best gladly served as a model for the clothing shop he opened on Manchester's Deansgate with friend and Manchester City player Mike Summerbee, in which casual Mod attire predominated. The clothing, referred to by Best as 'our new Mod stock' included button-down shirts, Prince of Wales checked trousers, slim fit jeans, suede jackets and slip-on Italian shoes. (18) Although other players, including Bobby Moore, dabbled with the fashion retail business, for Best the clothes store and related modelling served to heighten his unconventional crossover pop star image.

Football player 'types': from post-war austerity to 1960's affluence 
As indicated above, an intention of this essay is to identify a fashion category sitting between the Mod formal of Bobby Moore and the Mod casual of George Best, to account for the image of Martin Peters as sartorially expressed. In moving towards the discussion of Peters as 'quiet Mod' it is useful to consider a typology for post-war professional football players in Britain constructed by Chas Critcher. (20) The typology is fourfold: 1) the traditional/located player who continues to draw upon the established value system of the 'respectable working class'; 2) the transitional/mobile player who benefits from the improving financial rewards of football to enjoy a middleclass lifestyle; 3) the incorporated/embourgeoised player who becomes a small scale entrepreneur; 4) the superstar/dislocated player who becomes a celebrity bigger than the sport of football. (21)

The traditional//ocated player tends to be a player whose playing career was interrupted by WWII. The key characteristic is that the player saw himself as part of the local community, despite his relative fame and, as such, he stood as a representative of the working class. Such players were socially nurtured within an age of austerity to the extent that great economic reward from football was not part of their ambition. Their street dress was typical of the respectable working class and did not so much set them apart from other working men. Critcher names Stanley Matthews as typical of the traditional/located player, but two other players he mentions in passing, Tom Finney and Nat Lofthouse, who played their entire careers for their hometown clubs, Preston and Bolton respectively, are probably even better examples. (22)

The transitional/mobile player is from the generation of players born before WWII, but whose playing careers commenced in the post-war period. These players came into professional football prior to the abolition of the maximum wage in 1961, but were young enough to benefit from its rewards. They are likely to have been signed by ambitious and leading clubs at a young age and hence drawn away from their local areas. An affiliation remains to the working class, but this player is more aspirational than the traditional/located player. Critcher draws upon Arthur Hopcraft's characterisation of Bobby Charlton to identify him as a transitional/mobile player: "he 
lives in a rich man's house in a rich man's neighbourhood. He is the classic workingclass hero who has made it to glamour and Nob Hill'. (23)

The incorporated/embourgeoised player marks a further general step from the transitional/mobile player. These players tended to be born towards the latter years of WWII and became professionals just after the abolition of the maximum wage. Critcher appears to be critical of this category of player who he identifies as conformist, business-minded and 'hardly laden with heroic qualities'. (24) Critcher regards this type of player as 'anonymous', claiming that 'a whole generation of such men played for England in the middle and late 1960s'. Critcher blames the predominant tactics of the period - seemingly more than socio-economic issues - for the emergence of the incorporated/embourgeoised player. He contends that 'playing styles [became] more rigid: over-collective, remorseless and functional, the new demands were for the runner, the 'worker' who could fit into a preconceived pattern'. The obvious candidate being stereotyped here [and named by Critcher] is Alan Ball, the workaholic midfield player who ran tirelessly until the duration of extra-time in England's World Cup Final win of 1966. An unmentioned target of blame in Critcher's critical depiction of the incorporated/embourgeoised player is the England team manager from the period, Alf Ramsey. Ramsey conceived a playing system and selected players according to his perception of their ability to fit successfully into the system. (25) Judgements on Ramsey and his approach vary between those who see Ramsey as a tactical genius (he did, after all, devise the plan and pick the team that won England its only World Cup to date) and those who hold him responsible for devising an uncreative style of team football, which, subsequent to the World Cup success, became enculturated into English club football, resulting in much less attractive play than was previously known.

From Critcher's comment regarding the Ramsey protégé Alan Ball, it can be reasonably assumed that he is of the latter school of thought. And this view rather influences the shaping of the fourth category in his football player typology. The superstar/dislocated player emerged in rebellious response to the blandness of the incorporated/embourgeoised player both in football playing style and in off-field appearance and conduct. George Best, unsurprisingly, is given as the key example of the superstar/dislocated player and suggested as a prototype for subsequent highly 
talented, but rebellious, players who emerged in the late 1960s and early 1970s, including Rodney Marsh, Charlie George and Alan Hudson. (26) Critcher suggests that supremely talented and highly individualistic players could not be constrained by systematised playing methods and became 'dislocated' from the sport as well as from their cultural roots. In the case of the maverick players who followed Best this tended to result in them changing clubs quite frequently, in the case of Best, it resulted in him dropping out of top flight football in what should have been his prime.

However, a problem with Critcher's superstar/dislocated player type is that it accounts for players who are by far the exception rather than the rule. Even the maverick players who followed Best, despite the wayward lifestyles of some, did not match his superstar status. This undoubtedly had something to do with Best being the first of a rare kind and with his football career neatly coinciding with the emergence of the socalled 'swinging sixties'. Martin Peters' take on George Best is interesting in this regard:

In a way, he was a flag-bearer for youth, along with the Beatles, the Rolling Stones, Twiggy and Mary Quant, and he seemed to take that duty almost as seriously as his football commitments. This was the era of Ready, Steady, Go, miniskirts and Carnaby Street. The maximum wage for footballers had been lifted in 1961 and George was one of a growing number of famous young players who had money to spend and wanted to enjoy life. I was quite content to view the 'swinging sixties' from the back seats but George wanted to be in the thick of it. (27)

Peters continues by reflecting on his own reserved attitude to the lifestyle possibilities in the 1960s, There were temptations but I was reluctant to get too involved in the party scene in London'. (28) From here Peters compares himself not to Best but to Moore and Hurst, thus players who dabbled with the celebrity set, especially Moore, but did not let it impinge upon their careers. In terms of Critcher's typology, Peters' admission prompts his categorization as an incorporated/embourgeoised player, someone who accepted the authority of football management during a time of increasing control over player tactics and who was careful not to step out of line socially and in private life. But rather than simply labelling such a player as boring and non-heroic it is more fruitful to examine the player's unspectacular image, including dress, to see what nuances it may reveal. At this point it is appropriate to move further 
towards explaining the earlier mentioned identification of Peters with the potential category of 'quiet Mod', in contrast to the 'Mod formal' and 'Mod casual' associated, by Hewitt and Baxter, with Bobby Moore and George Best respectively. To do this requires a brief discussion of the so-named Mod youth culture in Britain. (29)

\section{Football and the 'incorporation' of Mod}

The Mod culture that took form in the early 1960s had roots in the jazz scene and its associated cool dress sense and then, in relation to music, the interest shifted to emergent forms of black genres; soul, rhythm and blues and the pop music coming out on the Tamla Motown record label. The live music scene was very important to the development of Mod culture, particularly in a select few London discothèques. English acts such as Georgie Fame and the Blue Flames and Chris Farlowe and the Thunderbirds did their own versions of material from black US performers such as James Brown, the Miracles and Mary Wells. The fashion focus was initially on suits, particularly the sharp Italian, slim lapelled and narrow legged style. London tailors soon adapted to the preparation of such garments, especially as relatively affluent young men were able to afford individually tailored suits and shirts. But money was no guarantee of cool credibility as knowledge on the detail of various features of clothing, for example, cuff length, suit vent size and positioning, the number of buttons and their size and positioning, was essential to acceptance within Mod culture. The first dedicated Mod band is generally believed to have been The Who. Their frenetic music, particularly the guitar work of Pete Townshend and the drumming of Keith Moon added a sense of danger to the Mod culture, which had by 1964 taken on a deviant public image owing to the hyperbolic media reportage of the seaside clashes between Mods and Rockers at Brighton and other locations. The emergence of The Who and other Mod bands, Small Faces being prominent, coincided with a shift around 1965 to the more casual type of Mod attire discussed earlier in the essay. This shift resulted in the Mod culture becoming more accessible to a greater number of youth. Put simply, a well-fitting pair of Levi denims, a Fred Perry shirt and a pair of desert boots (although by no means inexpensive) were more affordable than tailored suits and shirts and made-to-measure shoes. 
A number of factors, initially including the media attention given to the Mod 'rioters' at Brighton, followed by the commercial popularity of bands such as The Who, Small Faces and The Kinks, and the depiction of Mod fashion and music in films such as Up the Junction (1968), saw 'Mod' step beyond the realm of a subculture and go mainstream. This process, also applicable to other youth subcultures, has been referred to within cultural studies scholarship as 'incorporation', (30) and the term in that usage compares interestingly to that in Critcher's typology, i.e. the incorporated/embourgeoised player. Categories one, two and four within Critcher's model are invested with differing degrees of authenticity (most strongly in the case of category one, given the link to tradition and community) and, in the case of category four, the superstar/dislocated player type, originality. Within the typology, the incorporated/embourgeoised player is neither 'authentic' nor 'original'. He has drifted too far from the working class roots of football to be regarded as authentic, and is too compliant with the dictates placed upon him by football authority to be original. However, further consideration of the 'incorporation' of Mod into the cultural mainstream challenges the originality accredited to the superstar/dislocated player and the related easy assignation of other players into an 'anonymous' player type, whatever name it might be given.

The superstar/dislocated player type is usefully revaluated by considering its key example, George Best, in relation to the notion of 'incorporation'. As indicated above, Best explicitly associated himself with a Mod image when he discussed the clothing range coming into his Manchester boutique. He modelled the clothing and adopted it as his own everyday wear. However, Best was hardly a pioneer in the Mod fashion stakes. By this time he was a man in his early twenties and an entrepreneur cashing in on and bringing the popular apparel of Carnaby Street to retail accessibility in the north of England. (31) The 'incorporation' of Mod fashion into mainstream youth and young adult society was the key indicator of an outgrowth of Mod from its subcultural roots. 'Mod' became an associated buzzword with the so-called 'Swinging Sixties' and 'Swinging London' and was mentioned more in relation to the designs of Mary Quant than the self-styled fashions of the young hipsters with whom it had commenced. The coming of Mod fashion to the high-street also resulted in looser referential associations 
being made within popular cultural discourse. Thus, The Beatles were often referred to in the press as Mods, although they were never a part of the Mod scene and Merseybeat music in general was not embraced within the Mod subculture. (32) Relatedly, George Best's labelling as the 'fifth Beatle', as well as his self-attachment to the already commercialised variant of Mod fashion, offer rather poor credentials to being Mod, at least in a subcultural sense. Indeed, his relationship to the Mod subculture - put in the terms of cultural studies - is based in 'incorporation' rather than authenticity or originality. The aforementioned quote from Martin Peters on George Best acquires further interest in light of this interpretation. Peters does not mention Mod culture, but symbolically links Best to a number of the most familiarly referenced icons of 'Swinging Sixties' folklore: The Beatles, The Rolling Stones, Twiggy, Mary Quant, miniskirts and Carnaby Street.

\section{Martin Peters: the 'quiet Mod'}

Peters also mentions the television program Ready, Steady Go!, which screened on the ITV network between August 1963 and December 1966. The program featured leading top forty acts, including The Beatles, as well as Mod favourites The Who and The Kinks. It relied on minimal studio decoration and the dancing of a sharply dressed studio audience rather than staged choreography, thus creating a live club atmosphere that appealed to Mod viewers. (33) While Peters distances himself from any involvement with the bright lights of London nightlife in the 1960s, his autobiography does give indication of his own interest in music of the time. The relevant remark occurs when Peters reflects upon being left out of the winning West Ham United team for the 1964 FA Cup Final by manager Ron Greenwood. To console himself and relieve the disappointment, over the ensuing summer, Peters would listen to music played from offshore pirate radio. (34) Given that he is referring to the summer of 1964, Peters must have been listening to the first of the offshore pirate stations to broadcast in the UK, Radio Caroline. This would have exposed him to range of pop and rock music as Radio Caroline was not limited to items in the Hit Parade. (35) Peters was thus likely to have heard recordings that were also being played in the discothèques frequented by Mod youth. 
Martin Peters turned twenty-one on 8 November 1964 and married his fiancée Kathy on that same day. Earlier in the year he had informed the West Ham club that he intended to buy a home and secured their agreement to be guarantors. (36) From the time he joined West Ham as an apprentice in May 1959 at fifteen years of age Peters was well aware that he was making football a career choice. In his earlier autobiography, written in 1969, the year before his record breaking transfer to Tottenham Hotspur F.C., Peters remarked on how acutely aware he became of the continual warnings footballers received about the shortness of their careers and of impending poverty if they were not frugal with their money. With marriage in mind from the age of nineteen, Peters claims to have put all of his earnings 'straight into the bank'. (37) On a summer trip with West Ham to the United States in 1964 Peters limited his tourist activities to an 'excursion up the Empire State Building', preferring to save as much of his travel allowance and playing bonuses as possible. (38) By planning for married life, and assumedly a family, from late teen years Peters avoided the 'conspicuous consumption' associated with fashion based youth cultures of the 1960s. Mods were especially known to spend every available penny they could on keeping up a necessary 'exquisiteness of dress'. (39) But even looking back further into Martin Peters life there is little evidence to suggest he would have been drawn into the subcultural world of Mods, or any other fashion-based teen movement. From early years Peters was preoccupied with playing sport and as he advanced through school much of his time was spent in preparing for and playing representative level football, ultimately as an England Youth player. (40) Admittedly, we gain only a limited view into Peters' life from his autobiographical writing and, unsurprisingly, given that it is the reason for his prominence, football remains at the forefront of his storytelling. (41) Nevertheless, there is no reason to doubt that football predominated in his thoughts as a young person and took up time that may have been devoted to other activities.

Had Peters not gone into an apprenticeship for professional football his destiny was likely to be the same as many young working-class men in England, to follow the employment example of his father. (42) Peters' father was a lighterman who steered flat-bottomed, cargo laden barges along the Thames to Royal Victoria Dock. Peters 
explains that a lighterman's job was well regarded within the East End, as it involved considerable skill and afforded a decent wage. (43) Peters' father, indeed, wanted the young Martin to follow him as a lighterman and had to be persuaded to allow his son to forsake this future for football. Peters' preference for football in no way appears as a rebellious act against paternal advice, but the pursuit of an alternative ambition that matched mildly aspirational ends with which his parents would not have been at odds. Peters' young life involved a progression beyond the historically working-class East End. Born at Plaistow, one stop heading east from London along the District line from Upton Park, the location of West Ham United's home the Boleyn Ground, by the early 1950s Peters moved with his parents to a council estate in the increasingly industrialised suburb of Dagenham. The semidetached house he later bought as a young player in Hornchurch marked a further move along the District Line and a distinct step up the property ladder, although Peters carefully describes the location as a 'pleasant, unpretentious Essex Estate'. (44)

So, how might the term Mod be applied to Martin Peters? If the frugal, non-clubbing, young man cannot be described as Mod, then the answer would be not at all. This will, indeed, be the response for those who wish the term to remain strictly attached to its most devoted subcultural affiliates. Such restriction would not allow for the broader usage suggested by Hewitt and Baxter in their designations of 'formal' and 'casual' Mod footballers. As indicated above, neither Bobby Moore nor George Best were Mods in the subcultural sense, and although Best actually used the term to describe his own wardrobe this was well after a commercialised variant of Mod fashion had moved into the cultural mainstream. As knowledgeable as Hewitt and Baxter are about fashion and the Mod subculture they are undoubtedly aware of this distinction. Their purpose is to use 'Mod' as a referent to make sense of the fashion image presented by two of the key footballers of the 1960s. They are not actually proposing that Moore and Best were Mods as such. Moore and Best were obvious selections for their attention given that they were arguably the two highest profile footballers in England during the mid to late 1960s and, as already outlined, both known for their respective forms of stylish dress off the pitch. Accordingly, both were regularly photographed in their street attire. But other players of the era had a stylistic 
relevance, less noticeable, but at least significant in contrast to those of Moore and Best, and it is in this sprit that the 'quiet Mod' appearance of Martin Peters is considered towards the conclusion of this essay.

Following the World Cup success of 1966 the England players were sought after for advertising work. In an interesting example Martin Peters featured with Bobby Moore and wives Kathy and Tina in a television advertisement for the pub industry titled 'Look in at your local'. The ad showed the players entering a pub to join their wives for a game of darts and a beverage 'after the game'. Moore was clearly the 'star' of the ad, with the only speaking part, and he leads the way into the pub to the waiting wives with Peters following. Both Moore and Peters are wearing slim fitting suits with white shirts and dark narrow ties, Peters tie seems narrower than Moore's, much in the way of the photo below from around the same period in which they are joined by Geoff Hurst.

Illustration 1 to be inserted

To say that Peters has deliberately worn such a narrow tie to identify as a 'Mod' would be to overdo the point, but in a number of photos, ranging from the more formal (as above) to the more casual (as in Illustration 2), Peters evinces an understated Mod look. This look was enhanced by Peters' hairstyle, which, at least in the early part of his career was subtly Mod. Fortune perhaps played a role here. Even a photo from around eight years of age shows Peters with a naturally thick head of dark hair wellsuited to a forward sitting fringe. (45) In the early to mid-1960s Peters wore his hair in what may best be described as a longish college boy cut. Given that Ivy League clothing was one of the inspirations for Mod fashion, the college boy haircut was also in keeping with the Mod look. Indeed, the college cut continued to serve as the basis for moderately Mod hairstyles over time. The male haircuts that became more overtly identified with the Mod subculture, particularly those exhibiting the 'backcombing' style as worn by pop musicians, were overly dandyish and perhaps of limited everyday appeal even to young men fancying a modish appearance. (46) Such cuts were expensive, difficult to maintain and not likely to gain a favourable response with conservative minded employers. Accordingly, many a young 'Mod' had a hairstyle more like Martin Peters than Rod Stewart or Steve Marriott. 
Many of the male fans of these pop stars were also likely to dress in a way more resembling Peters than their music idols. The photo below shows Peters with Bobby Moore taking a stroll just outside the grounds of the England team's headquarters at Hendon Hall Hotel, north of London, on the morning of the 1966 World Cup quarterfinal match against Argentina.

\section{Illustration 2 to be inserted}

The date is $23 \mathrm{~J} \mathrm{uly,} \mathrm{hence} \mathrm{the} \mathrm{summer} \mathrm{attire.} \mathrm{Peters} \mathrm{wears} \mathrm{what} \mathrm{is} \mathrm{now} \mathrm{regarded} \mathrm{as}$ a classic item of Mod casual dress, the Fred Perry short-sleeved polo shirt. Conceived by the famous English tennis player turned designer, the shirt initially intended for wear while playing tennis soon became, as occurred with other brands, an off-therack fashion item of everyday attire. (47) Peters matches his Fred Perry shirt with a faintly patterned pair of Princes of Wales trousers, pleat-fronted and appropriately worn waist high. His ensemble is finished off with, what appears to be, a pointed toe pair of slip-on faux crocodile shoes or boots. While Moore is immaculate in his casual attire and imposing with his upright gait, it is Peters dress that most exhibits an affinity with Mod sensibility down to the key signifier of having the polo shirt tucked into the trousers. Mod aficionados may point to deficiencies in Peters' presentation, such as the Fred Perry shirt being a bit baggy and the top button being left undone. However, the point here is not to advance a case for Peters having been a Mod fashion leader, but to propose that his appearance suggested sympathy with the Mod look as an everyday style for young men in the 1960s.

Other photographs from the early 1960s show Peters wearing garments such as turtle neck jumpers, trench coats and slim, straight legged trousers with the cuff length just to the top of the shoes; all indicators of a Mod affinity. In a few photos Peters can be seen wearing jumpers by Slazenger, another label for tennis and golf wear that was not out of place in the Mod wardrobe. (48) In a photo at home Peters wears a Slazenger V-neck pullover with a white shirt and patterned thin tie. (49) This intermediate look between formal and casual would have been suitable attire for young Mod minded men working in city offices. This observation raises further query about the football player typology of Critcher. Peters, as noted above, is a prime candidate for the incorporated/embourgeoised player type within that model. Yet, 
Peters actually had a key characteristic of the traditional player type as set out by Critcher in that his off field dress was, at times, very similar to those young men of working-class background in the 1960s, who took up employment in white collar work - unlike the generation of men before them - requiring smart dress. The typology, as devised by Critcher, does not allow for this significant change in labour and associated fashion history. Accordingly, the type of player suited to his incorporated/embourgeoised category is rather inaccurately separated symbolically from his male age cohort. Put simply, if we can say that Stanley Matthews dressed like many of the young men who followed him as a footballer in the late 1940s and 1950s, so too we may say that by the mid-1960s, Martin Peters dressed like many of the young men who would have supported him as a West Ham United and England player. (50)

\section{Conclusion}

As much as fashion was affected by the, often-mentioned, shift from the 'austerity' of post-war Britain to 'affluence' in the 1960s, caution needs to be taken against overstatement. Following a journey on the London Underground in August 1966, Prudence Glynn, fashion correspondent for The Times, wrote, with a sense of slight surprise, that the young women she observed riding in her compartment where 'dressed in relatively sober, predicable clothes'. (51) Perhaps she may not have expected as much in dress from young men, but, whatever the case, the overall colourful image of the 1960s was an exaggeration, and this exaggeration has been enhanced with the passing of time. It may well be the case in regard to football that the fashionability of George Best marked an historical turning point in the celebrity status and glamour of the sport in the 1960s. (52) Yet, Best was a rarity. Only a handful of 'star' players from his time through to the present day, including the relatively insipid David Beckham, have attracted media attention for their appearance in the heralded manner of popular music and movie stars. Certainly the 'two spheres' of football and fashion share enough common ground to warrant investigation into how 'their histories and developing interests have constantly overlapped'. (53) Part of this attention rightly goes to celebrity figures such as George Best, but this should not 
result in a focus that overlooks the more inconspicuous fashion identities of other footballers. Accordingly, this paper has concentrated on one of Best's contemporaries, Martin Peters, with a view to examining that player within the Mod framework proffered by Hewitt and Baxter. The less obvious Mod inspired appearance of Peters has prompted reference to an alternative category, the 'quiet Mod'. His case provides another view of the connection between a football player of the time and 1960's fashion sensibility. Peters did not make a fashion statement as such, rather his off field attire and presentation subtly reflected the popularized Mod look. But this is a reason for looking at his image more closely; studies of the sport/fashion nexus have tended to look at the spectacular, the purpose of this paper has been to shift emphasis onto the cultural historical significance of the unspectacular.

\section{Notes}

1. Tony Pawson, The Goalscorers: From Bloomer to Keegan (London: Cassell, 1978), 54.

2. Martin Tyler, Boys of '66: The England Team that Won the 1966 World Cup Then and Now (London: Hamlyn, 1981), 124; Dennis Irving, The West Ham United Football Club Book (London: Stanley Paul, 1968), 120.

3. Paolo Hewitt and Mark Baxter, The Fashion of Football: From Best to Beckham, From Mod to Label Slave (Edinburgh: Mainstream, 2004). Although not an academic work, this book offers an interesting starting point on the football and fashion intersection from which scholarly studies can develop.

4. Chas Critcher, 'Football since the War', in Working Class Culture: Studies in History and Theory, ed. John Clarke, Chas Critcher and Richard Johnson (London: Hutchinson, 1979) 161-84.

5. Richard Lewis, England's Eastenders: From Bobby Moore to David Beckham (Edinburgh: Mainstream Publishing, 2002), 55. A sobering take on the impact on West Ham United having three players involved in the World Cup Final is provided by Charles Korr, West Ham United: The Making of a Football Club (London: Duckworth, 1986) 167.

6. Martin Peters, The Ghost of '66: Martin Peters the Autobiography, with Michael Hart (London: Orion, 2006), 54.

7. Ibid., 54-5.

8. Ibid., 54.

9. Hewitt and Baxter, The Fashion of Football, 31.

10. Peters, The Ghost of '66, 59. 
11. Hewitt and Baxter, The Fashion of Football, 33-4.

12. Ibid., 36.

13. Ian MacDonald, Revolution in the Head: The Beatles Records and the Sixties (London: Vintage, 2008, $3^{\text {rd }}$ rev. ed.), 83.

14. David Lacey, 'Brilliant, Brave and as Big as the Beatles: George is the Best', The Guardian, Wednesday 30 J uly 2008, Sport section, 7.

15. Hewitt and Baxter, The Fashion of Football, 46.

16. Gordon Burn, 'The Unravelling of George Best', The Guardian, Friday 25 November 2005, G2 section, 8. It seems reasonable to believe that Best's seduction into a new age of glamour distracted his focus from football to the point where he withdrew from the one activity in which he achieved true aesthetic expression, of. Stephen Gundle and Clino T. Castelli, The Glamour System (Basingstoke: Palgrave Macmillan, 2006), 85.

17. An amusing episode of admonition from Manchester United manager Matt Busby falling on George Best's 'deaf ears' is recounted by Gordon Burn, Best and Edwards: Football, Fame and Oblivion (London: Faber and Faber, 2006), 16.

18. Hewitt and Baxter, The Fashion of Football, 48.

19. Moore's ventures into the fashion retail business were unfortunately unsuccessful. J eff Powell, Bobby Moore: The Life and Times of a Sporting Hero (London: Robson Books, 2002), 224-5.

20. Chas Critcher, 'Football since the War'.

21. I bid., 164.

22. I bid. While providing a useful analytical framework, Critcher's typology tends to promote historical dissimilarities between generations of footballers over certain similarities that occurred across time. For example, by the mid-1930s some players were dressing in tailored suits and silk shirts, thus in a manner very different from their working class male supporters (and, thus, contrary to the traditional/located players within Critcher's typology). Rather than exhibiting ostentatiousness, this sartorial choice reflected a desire for 'respectability' that continued with footballers in subsequent post-war decades. Matthew Taylor, 'Work and Play: The Professional Footballer in England c. 1900 - c. 1950', The Sports Historian 22, no. 1 (2002): 16-43.

23. Ibid., 165; Arthur Hopcraft, The Football Man (London: Aurum, 2006 [1968]), 86.

24. Critcher, 'Football since the War', 165.

25.J onathan Wilson, Inverting the Pyramid: The History of Football Tactics (London: Orion, 2008), 42-52; For a discussion of how Martin Peters fitted into the England team playing system developed by Ramsey in 1966, see Dave Bowler, 'Winning Isn't Everything...': A Biography of Sir Alf Ramsey (London: Victor Gollancz, 1998), 197. 
26. Critcher, 'Football since the War', 167; This theme is pursued by Rob Steen, The Mavericks: English Football When Flair Wore Flairs (Edinburgh: Mainstream Publishing, 1994).

27. Peters, The Ghost of '66, 137.

28. I bid. A critical position on the England 1966 World Cup team being 'assimilated' into overblown accounts of 'Swinging London' is taken by Dil Porter, 'Egg and Chips with the Connellys: Remembering 1966', Sport in History 29, no. 3 (2009): 519-539 [529-30].

29. A number of works have been drawn upon to inform the discussion of Mod culture: Richard Barnes, Mods! (London: Plexus, 1991[1979]); Andy Bennett, Popular Music and Youth Culture: Music, Identity and Place (Basingstoke: Macmillan, 2000); Iain Chambers, Urban Rhythms: Pop Music and Popular Culture (Basingstoke: Macmillan, 1985); Dick Hebdige, The Meaning of Mod' in Resistance through Rituals: Youth Subcultures in Post-war Britain, ed. Stuart Hall and Tony J efferson (London: Hutchinson, 1976) 87-96; Paolo Hewitt and Mark Baxter, The A to Z of Mod (London: Prestel, 2012); George Melly, Revolt into Style: The Pop Arts (New York: Anchor, 1971[1970]); Tony Thorne, Fads, Fashions and Cults: From Acid House to Zoot Suit (London: Bloomsbury, 1993).

30. Stanley Cohen, Folk Devils and Moral Panics (London: Paladin, 1973); Dick Hebdige, Subculture: The Meaning of Style (London: Methuen, 1979).

31. Without reference to Mod culture, Christopher Breward, Fashioning London: Clothing and the Modern Metropolis (Oxford: Berg, 2004) 151-63, provides an interesting account of Chelsea, Kensington and the King's Road as more enduring hotspots of dandyish and suave youth fashion than Carnaby Street in early to mid-1960's London.

32. Barnes, Mods!, 13.

33. Chambers, Urban Rhythms, 75-6.

34. Peters, The Ghost of '66, 41.

35. Chambers, Urban Rhythms, 54-5.

36. Peters, The Ghost of ' 66,42 . Acting as a guarantor for mortgages was an aspect of the 'parental' role the West Ham club adopted towards it players, Korr, West Ham United, 171.

37. Martin Peters, Goals From Nowhere!, as told to Peter Corrigan (London: Stanley Paul, 1969), 71-2.

38. Ibid., 72.

39. Hebdige, The Meaning of Mod', 89.

40. Peters, The Ghost of '66, 22.

41. The problematic nature of 'sports autobiographies' is a matter of discussion within contemporary scholarship. See especially, Matthew Taylor, 'From Source to Subject: Sport, History, and Autobiography', Journal of Sport History 35, no. 3 (2008): 469-491; Martin Peters' early biography (1969) is focussed on the development of his football career. His post-retirement autobiography (2006) 
goes further, reflecting upon the intersection of his personal life and times with football. Nevertheless, its primary concern remains with Peters' self-profiling as a 'model professional'. This is in keeping with an enduring tendency in footballer autobiographies, as identified by Joyce Woolridge, These Sporting Lives: Football Autobiographies 1945-1980', Sport in History 28, no. 4 (2008): 620640.

42. The outstanding academic account of this tendency is Paul Willis Learning to Labour: How Working-class Kids Get Working-class Jobs (Farnborough, Hants: Saxon House, 1977).

43. Peters, The Ghost of '66, 10-11.

44. Ibid., 42.

45. Peters, The Ghost of ' 66 , first page of photos section, following page 88.

46. A consideration of Mod culture within the history of English dandyism is undertaken by Elizabeth Wilson, Adorned in Dreams: Fashion and Modernity (London: I.B. Tauris, 2003), 179-93.

47. Diane Élisabeth Poirier, Tennis Fashion (New York: Assouline, 2003), 36.

48. Slazenger supplied the footballs for the 1966 World Cup. The England playing kit was supplied by Umbro. Harold Mayes, The Football Association World Cup Report 1966 (London: William Heinemann, 1967), 71.

49. Peters, Goals From Nowhere!, fifth page of photos section, following page 64.

50. The historical background to young London men employed as clerks 'embodying' a 'controlled' appearance is discussed by Alison Goodrum, The National Fabric: Fashion, Britishness, Globalization (Oxford: Berg, 2005), 175.

51. Cited in Dominic Sandbrook, White Heat: A History of Britain in the Swinging Sixties 1964-70 (London: Abacus, 2007[2006]), 248.

52. Barry Smart, The Sport Star: Modern Sport and the Cultural Economy of the Sporting Celebrity (London: Sage, 2005), 72-4.

53. Christopher Breward, 'Pure Gesture: Reflections on the Histories of Sport and Fashion', in Fashion VSport, ed. Ligaya Salazar (London: V\&A Publishing, 2008) 16-39. 